\title{
Fossil Fish Teeth in Phosphatic Series of Jebel Dyr (Algerian-Tunisian Border Area)
}

\author{
Boulemia Salim, Hamimed Messaoud \\ Department of Earth Sciences and the Universe, Larbi Tebessi University, Tebessa, Algeria \\ Email: boulemia_salim@yahoo.fr
}

How to cite this paper: Salim, B. and Messaoud, H. (2018) Fossil Fish Teeth in Phosphatic Series of Jebel Dyr (Algerian-Tunisian Border Area). Open Journal of Geology, 8, 1069-1083. https://doi.org/10.4236/ojg.2018.812065

Received: June 29, 2018

Accepted: November 3, 2018

Published: November 6, 2018

Copyright $\odot 2018$ by authors and Scientific Research Publishing Inc. This work is licensed under the Creative Commons Attribution International License (CC BY 4.0).

http://creativecommons.org/licenses/by/4.0/

\begin{abstract}
The Thanetian phosphatic series of Jebel Dyr syncline, northeastern Algeria, are analyzed for their paleontological content. Materials were concentrated by sample washing and outcrops surface collecting of friable phosphorites facies, yielding a multitude of phosphatised fish teeth rich in species of variable morphology, representing 28 species of Elasmobranchii. The fish fauna indicates tropical to temperate paleo-environmental conditions. Most of the species represent benthic/nektonic forms of coastal areas with neritic and midwater depths of the continental slope.
\end{abstract}

\section{Keywords}

Thanetian, Phosphatic Series, Algeria, Elasmobranchii, Palaeoenvironment

\section{Introduction}

The Thanetian phosphatic series of the Algerian-Tunisian border region and their paleontological contents are still insufficiently known, despite the contributions of [1] [2] [3].

The fish fauna characterizing these rocks includes a multitude of species represented by teeth and some isolated vertebrae. We have studied tens of samples collected from phosphatic outcrops of the southeastern flank of Jebel Dyr (Figure 1). For the first time, we characterise and establish a general systematic overview of the many fish (elasmobranchs). Furthermore, the assemblages are analysed in order to reconstruct the paleoenvironment during this upper Paleocene period individualized by phosphatogenesis in the area.

Teeth of sharks and rays are characterised by strong heterodontism leading range of morphological disparity [4] [5] [6] [7] described several kinds of heterodonty: monognathic (e.g. in Odontaspididae and Rajidae), dignathic (e.g. in 
Carcharhinidae), and ontogenetic (in Hétérodontidiformes). Despite the fact that the heterodontism makes identification of fish species a very difficult task, we were able to identify almost of isolated material at the species level. The characterisation of species was mainly performed based on palaeo-ichthyology literature (e.g.; [8]-[20]). Materials (figured or not) are currently deposited at Tebessa University and referred with collecting number LT.

\section{Overviews of Geographic and Geological Settings}

The study area Jebel Dyr syncline (Figure 1(a) \& Figure 1(b)) forms part of the Saharan Atlas of eastern Algerian-Tunisian border area, extending to Tunisia. It is situated $20 \mathrm{~km}$ Northeast of Tebessa city, the capital province. The main geological Paleocene-Eocene formations of Jebel Dyr encountered at site (Figure

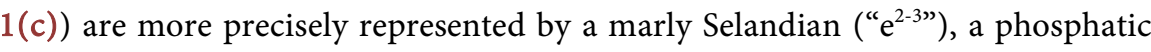

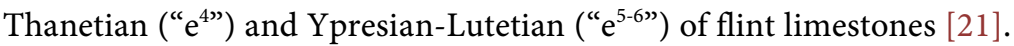

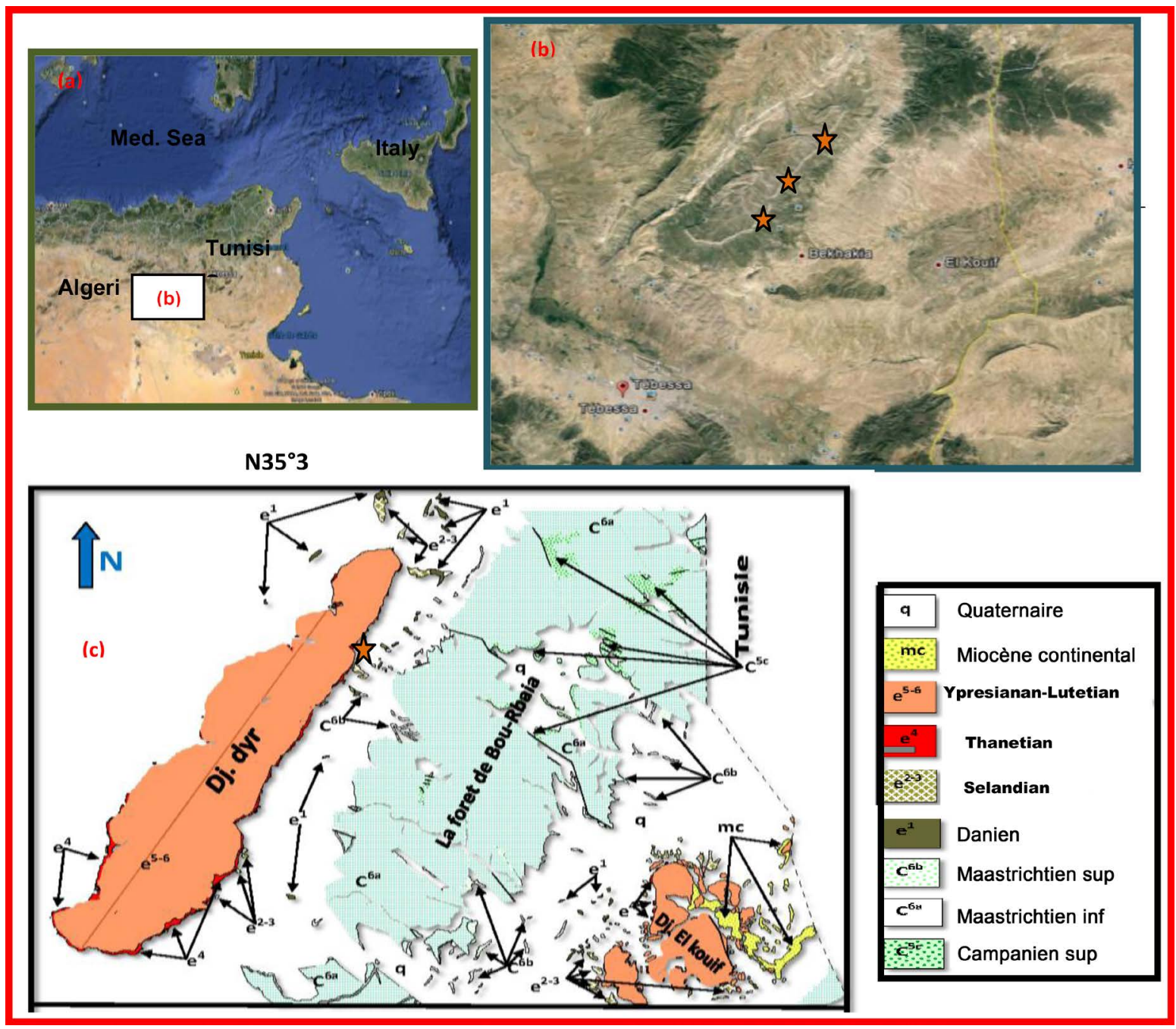

Figure 1. Geographic and geologic position of the study area: (a) Overview; (b) Location of the Jebel Dyr sections in Tebessa region (Google earth, 2015); (c) Simplified geological map of the Tebessa Basin (extract from geological map of Algeria 1/50,000). Red star: The Jebel Dyr sections. 


\section{Methods and Materials Used}

Jebel Dyr sector research was carried out during 2015-2016. The sampling of Thanetian phosphatic layers (total rock) was systematically conducted on outcrops of three sections crossing the southeastern slope of Djebel dyr. The hard layers, with dolomite cement, make the collection of teeth impossible by existing means, therefore, were not sampled. Concurrently, direct investigations for teeth were carried out on the field. However, the most important collecting of teeth materiel was completed after washing the sediment in the Laboratory of Geosciences at the Tebessa University in Algeria. Clean residues were obtained from pre-dried sediment samples washed over a standard set of nested sieves (the last sieve used of a fine mesh is $0.1 \mathrm{~mm}$ ) after disaggregation in tap water mixed with a wetting agent (detergent). Some samples need subsequent treatment with 5\% $10 \%$ hydrogen peroxide $\left(\mathrm{H}_{2} \mathrm{O}_{2}\right)$, neutralised with a few drops of ammonia. Fossils were picked from dried residues under a binocular microscope.

Photographs and measurements were taken, where appropriate, to aid in identification. Specimens were subsequently identified to genus level.

Unfortunately many Elasmobranchii teeth are incomplete or broken (existing of just crown or part of the root). These teeth are not resistant to postmortems mechanical damage. So, many of these cannot be identified or determinable to the family level only.

\section{Results and Discussion}

Fieldwork through three parallel sections (Figure 1(b)), carried out on the outcrops of Djebel Dyr formation(Figure 2(a)), which shows sub-tabular layers, as well as the laboratory tasks, allowed us to combine and finalize a stratigraphic $\log$ for this site(Figure 2(b)). This lithostratigraphic column established shows a formation revealing 08 layers of phosphates of Thanetian age, relatively friable of decimetric order, alternating with layers of limestone and marl-limestone and two layers of hard phosphates supported in Ypresian flint limestone to at the top.

The Thanetian fish assemblages of sampled phosphate of Jebel Dyr formation include many remains cartilaginous fish. Twenty-eight species (Elasmobranchii) are identified (Table 1), (Figures 3-6), twenty-three of which are sharks (Euselachii), however only five are rays (Batoidea). All together, they represent eighteen families of eight orders (Table 1). Systematic specification of these fossil groups has not been published previously for the Paleogene basin of the Algerian-Tunisian border area.

The Lamniformes with 9 species and $25 \%$ of the total number of collected specimens are the most diverse order. Among the frequented occurring, Odontaspididaes (Brachycarcharias and Carcharias) are the most abundant, flowed by Mitsukurinidaes and Otodontidaes. Next in abundance are the Carcharhiniformes with 6 species and $\sim 23 \%$ of the total number of specimens. The Myliobatiformes are represented by 4 species and close to $14 \%$. Among them, the rare presence of 


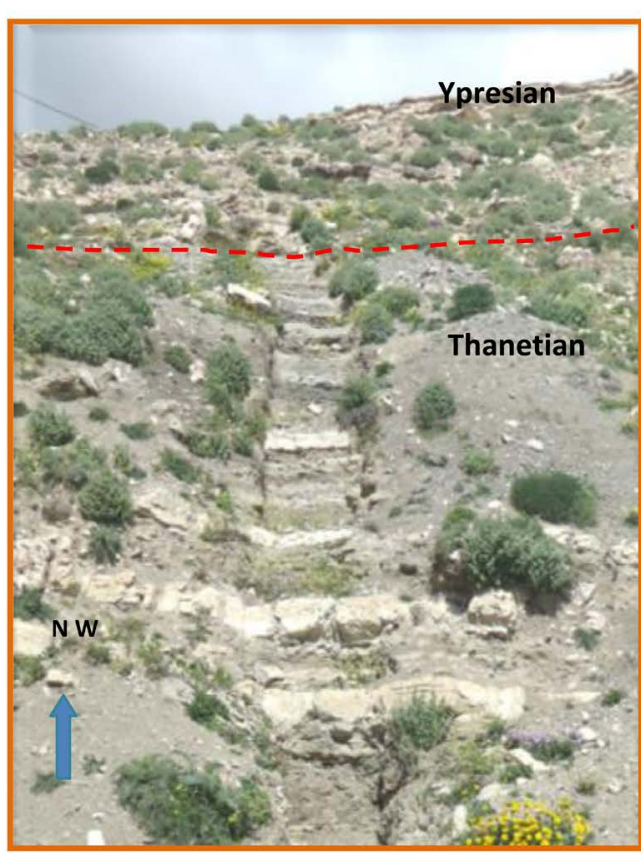

(a)

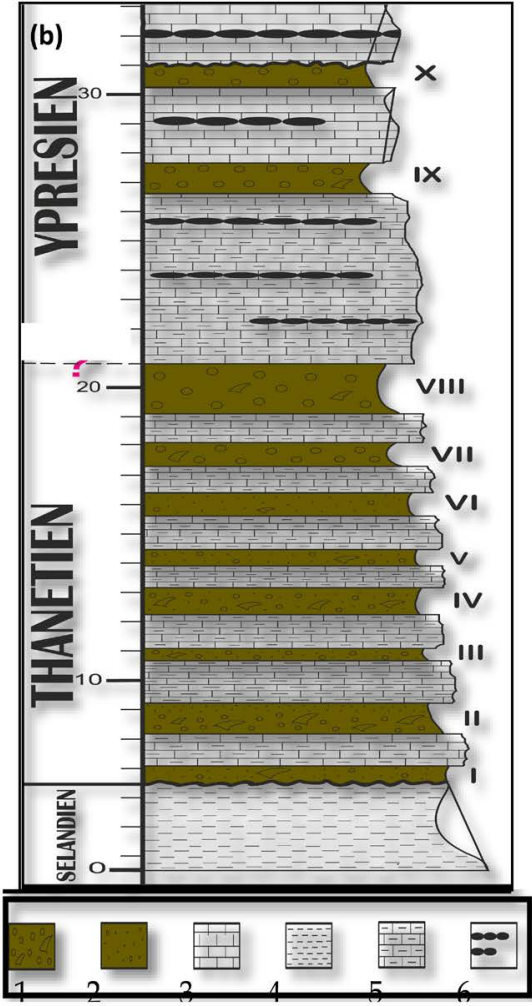

Figure 2. (a) Field photograph of a view (section) represents the profile of the southeastern side towards the North showing Outcrops the Ypresian-Thanetian formation of Djebel Dyr; (b) Lithostratigraphy of the: the studied Djebel Dyr sections with phosphorites layers 1 to 10 indicated; $1=$ coarse-grained phosphorites; $2=$ fine-grained phosphorites; $3=$ limestone; $4=$ marl; $5=$ marly limestone; 6 = chert.

Table 1. Systematic overview of fish species identified from Thanetian phosphatic series of Jebel Dyr.

\begin{tabular}{|c|c|c|}
\hline Order & Family & Species \\
\hline \multirow[t]{9}{*}{ Lamniformes Berg, 1958} & \multirow[t]{3}{*}{ Odontaspididae Müller \& Henle, 1839} & Brachycarcharias lerichei (CASIER, 1946) \\
\hline & & Carcharias hopei (Agassiz, 1843) \\
\hline & & Odonstaspis winkleri Leriche, 1905 \\
\hline & \multirow[t]{2}{*}{ Mitsukurinidae Jordan, 1898} & Striatolamia striata (Winkler, 1874) \\
\hline & & Anomotodon novus (Agassiz, 1843) \\
\hline & \multirow[t]{2}{*}{ Otodontidae Glückman 1964} & Otodus obliquus Agassiz, 1843 \\
\hline & & Cretalamna appendiculata (Agassiz 1843) \\
\hline & Lamnidae J. P. Müller and Henle, 1838 & Isurolamna affinis (Casier, 1946) \\
\hline & Jaekelotodontidae Gluckman 1964 & Mennerotodus sp. \\
\hline \multirow[t]{6}{*}{ Charcharniformes Compagno, 1973} & \multirow{2}{*}{$\begin{array}{l}\text { Carcharhinidae Jordan \& Evermann, } \\
1896\end{array}$} & Abdounia beaugei (Arambourg, 1935). \\
\hline & & Physogaleus secundus (Winkler, 1874) \\
\hline & \multirow[t]{3}{*}{ Triakidae Gray, 1851} & Galeorhinus mesetaensis (Noubhani \& Cappetta, 1997) \\
\hline & & Palaoegaleus vincenti (Daimeries, 1888) \\
\hline & & Mustelus biddlei Baut \& Genault, 1995 \\
\hline & Scyliorhinidae Gill, 1862 & "Scyliorhinus" gilberti Casier, 1946 \\
\hline Squatiniformes Debuen, 1926 & Squatinidae Bonaparte, 1838 & Squatina prima (Winkler, 1874) \\
\hline
\end{tabular}




\section{Continued}

Heterodontiformes Berg, 1937

Orectolobiformes Applegate, 1972

Myliobatiformes Compagno, 1973
Heterodontidae Gray 1851

Ginglymostomatidae T.N. Gill, 1862

Orectolobidaes Jordan \& Fowler, 1903

Pristidae Bonaparte, 1838

Myliobatidae Bonaparte, 1838

Dasyatidae Jordan, 1888

Mobulidae GILL 1893

Rajidae Bonaparte, 1831

\section{Heterodontus $s p$}

Nebrius bequaerti (Leriche, 1920)

Delpitoscyllium africanum (Leriche, 1927)

Ginglymostoma subafricanum Arambourg 1952

Hemiscyllium daimeriesi (Herman, 1972)

Squatiscyllium nigeriensis (WHITE, 1934)

Pristis $s p$

“Myliobatis" sulcidens Dartevelle \& Casier, 1943

Dasyatis hexagonalis Arambourg 1952

Archaeomanta priemi Herman 1979

Burnhamia daviesi (Woodward, 1889)

Raja $s p$

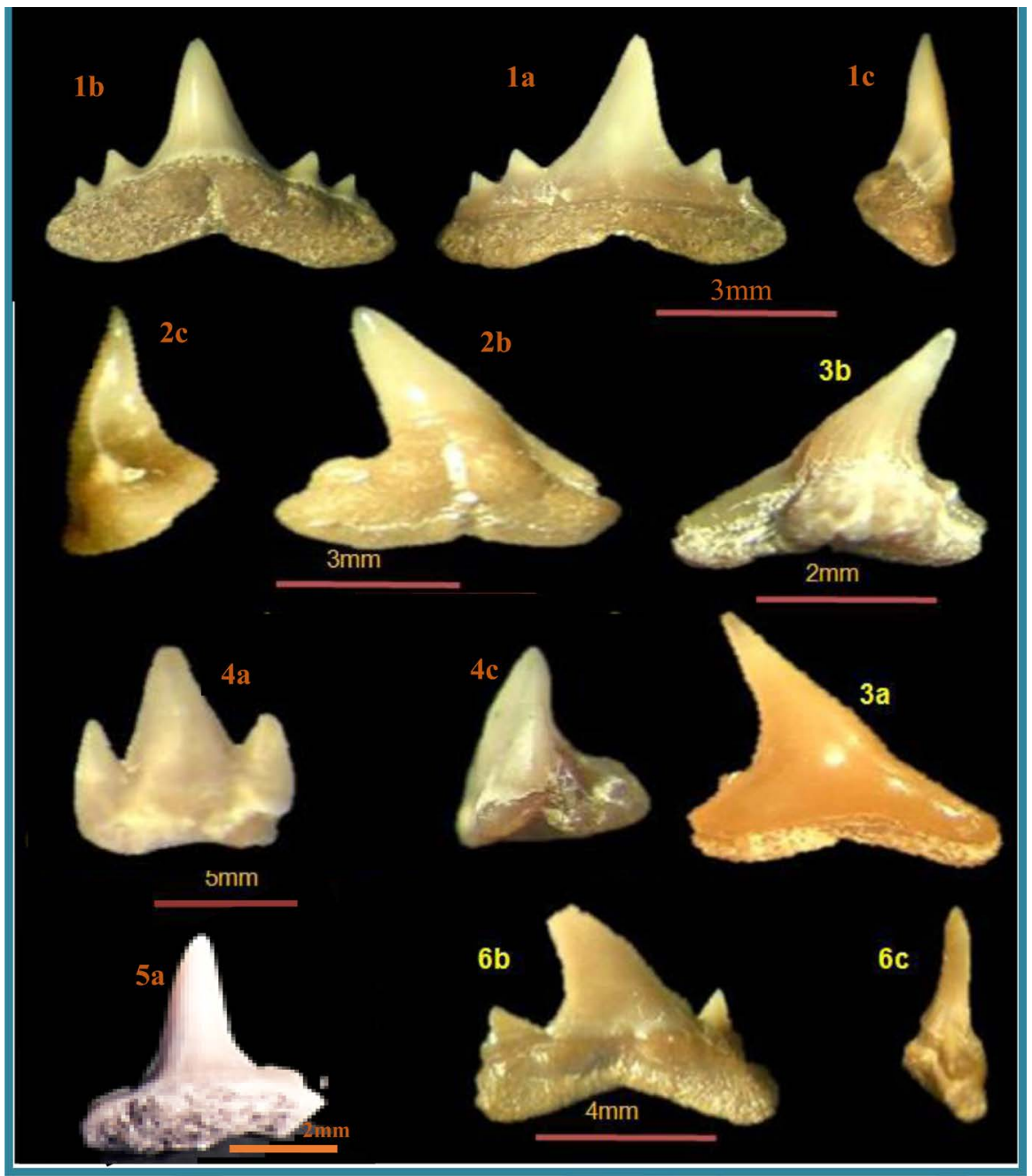

Figure 3. Elasmobranchs teeth from the Thanetian phosphatic serie of Jebel Dyr (Algerian-Tunisian border area); 1. Abdounia beaugei; 2. Palaoegaleus vincenti; 3. Galeorhinus mesetaensis; 4. Delpitoscyllium africanum; 5. Squatina prima; 6. Brachycarcharias lerichei. a: labial; b: lingual; c: lateral; d: occlusal views. 


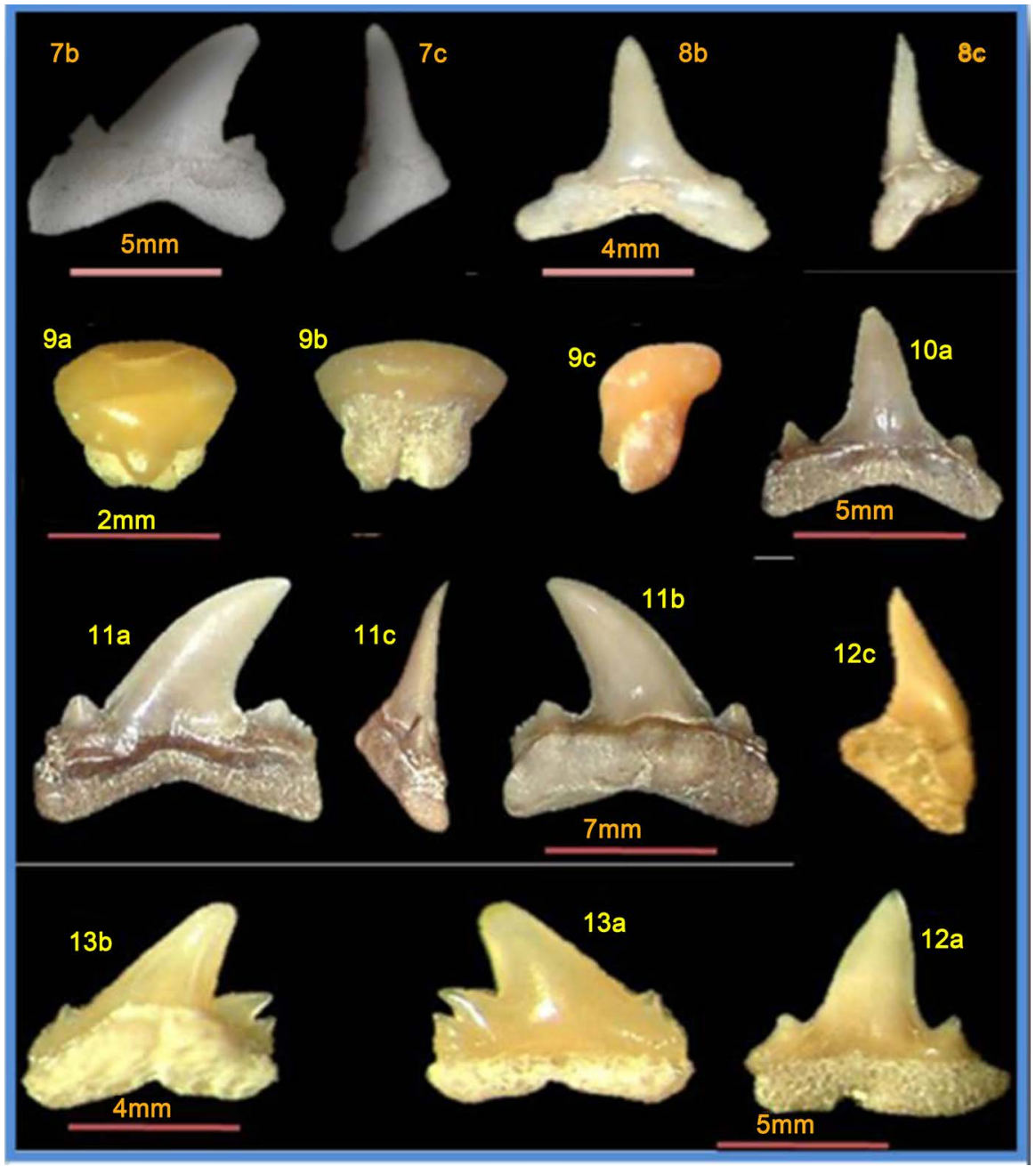

Figure 4. Elasmobranchs teeth from the Thanetian phosphatic serie of Jebel Dyr (Algerian-Tunisian border area); 7. Brachycarcharias lerichei; 8. Anomotodon novus; 9. Mustelus biddlei 10. Brachycarcharias lerichei; 11. Mennerotodus sp; 12. Abdounia beaugei; 13. Galeorhinus mesetaensis. a: labial; b: lingual; c: lateral views.

Myliobatidae (mollusc predators, common in high energetic shallow environments) is surprising. Orectolobiformes represented by four species are also, frequent with $14 \%$. The families of the Squatinidae, the Heterodontidae, Rajidae and Pristidae each represented by a single species, are less frequent and together represent nearly $24 \%$ of the total number of specimens.

Table 2 summarizes dentition types based on [6] [12] [22] and main features of the teeth collected at the Jebel Dyr Thanetian phosphorites, demonstrating that, in spite the spectacular diversity of the assemblage, teeth of sharks represent similar trophic adaptations [22] [23]:

- Tearing type in Odontaspididae, Mitsukurinidae and Jaekelotodontidae. The teeth of this type generally have well developed sharp edges and often one or more pairs of sharp lateral denticles, whereas the email of the lingual surface of the crown can be smooth. The fish of this type prefer near the coastal environments or leave near the bottom in deep water. 
- Cutting Type in Otodontidae and Lamnidae. The teeth in this group are wide, have a high crown, erect and fairly flat (Otodus). The functional row of teeth forms a sharp, more or less continuous blade; where the teeth are separated from each other. Forms of this type are nekto-pelagic.

- Cutting-Clutching type in Carcharhinidae. Teeth flattened with a large crown and high root. They are interlocked making an integral thread. The cusps allow to retain the prey, while the flattened teeth of the other jaw act in the manner of a guillotine.

- Clutching type in Ginglymostomatidae, Hemiscylliidae and Orectolobidaes. The teeth are poorly differentiated generally provided with lateral denticles for prey holding. The fish of this type prefer benthic habits, living close to the bottom.

- Crushing type in Myliobatidaes, Squatinidae and Rajidae. These teeth have a morphological diversity from forms with totally, smooth teeth (Raja). The crowns have bumpy surfaces. The teeth are staggered and closely intertwined. Fish with this dentition prefer a benthic lifestyle.

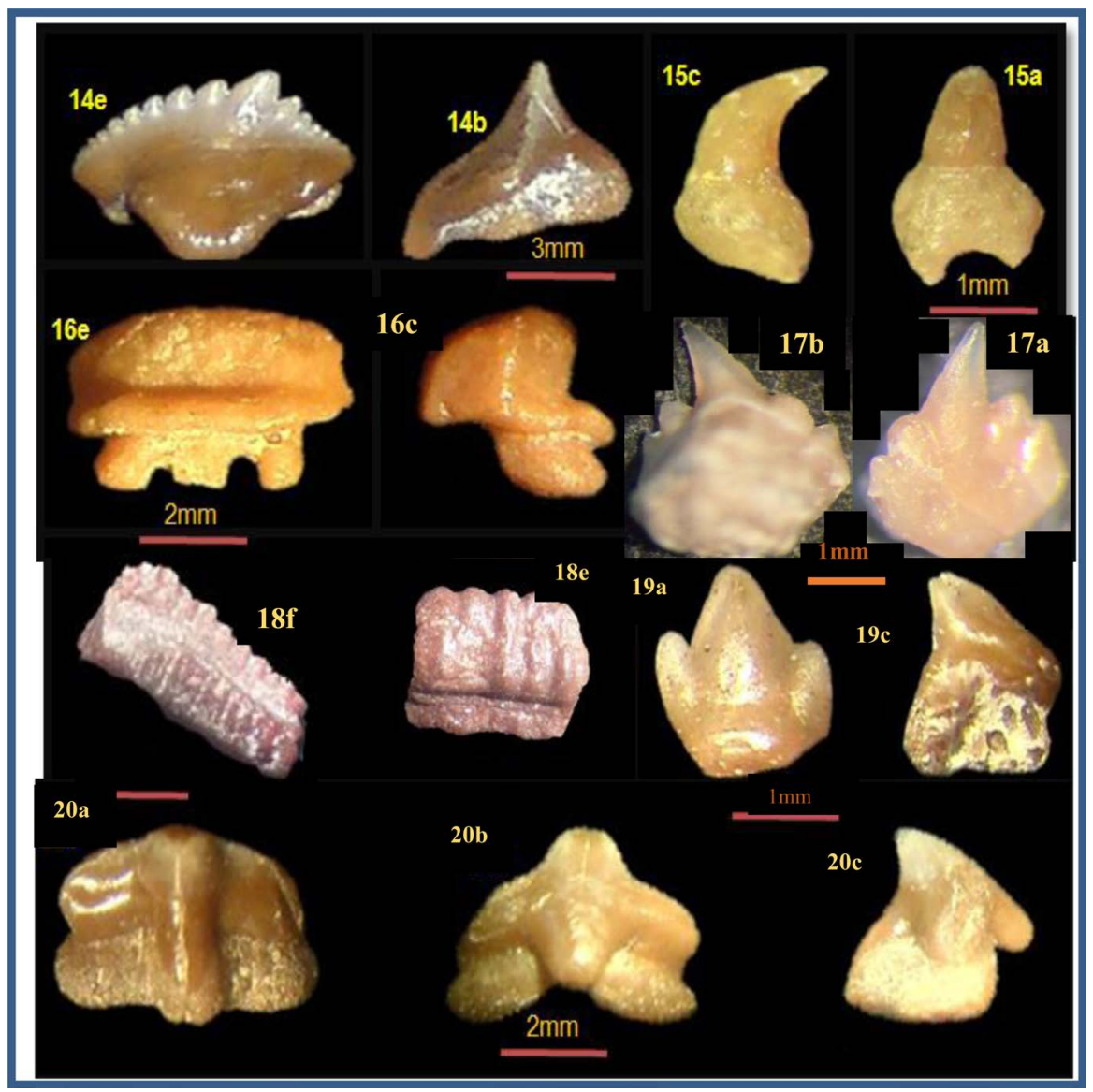

Figure 5. Elasmobranchs teeth from the Thanetian phosphatic serie of Jebel Dyr (Algerian-Tunisian border area); 14. Nebrius bequaert; 15. Archaeomanta priemi; 16. Burnhamia daviesi; 17. Ginglymostoma subafricanum; 18. Myliobatis sulcidens, 21. Hemiscyllium daimeriesi; 23. Squatiscyllium nigeriensis. a: labial; b: lingual; c: lateral; d: occlusal; e: oral; f: basilar views. 


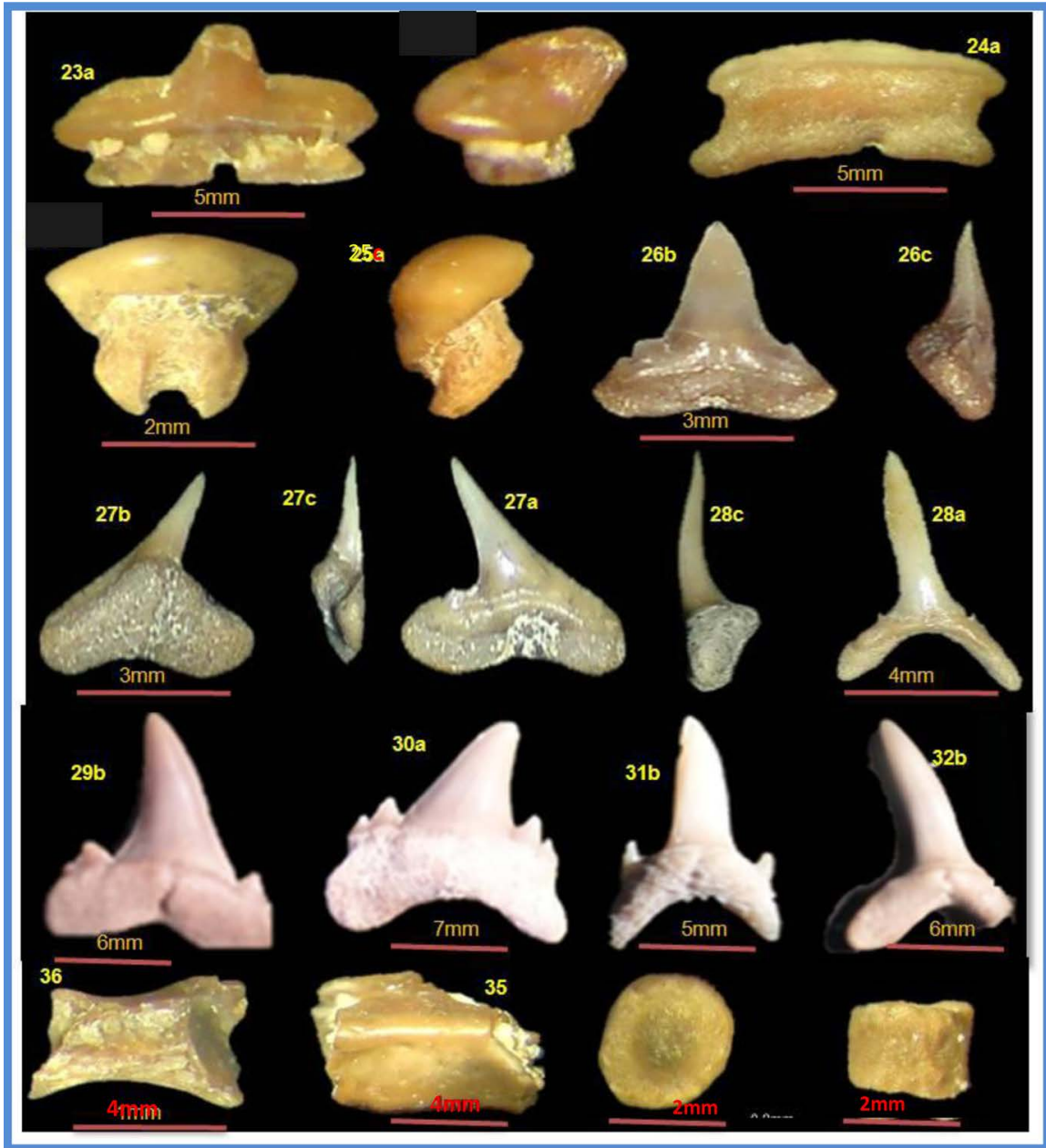

Figure 6. Elasmobranchs teeth and vertebrae from the Thanetian phosphatic serie of Jebel Dyr (Algerian-Tunisian border area); 23. Raja sp.; 24. Heterodontus sp.; 25. Dasyatis hexagonalis; 26. Abdounia beaugei; 27. Physogaleus secundus; 28. Carcharias hopei; 29-30. Cretalamna appendiculata; 31. Brachycarcharias lerichei; 32. Isurolamna affinis, 33-36. Sectioned fossil vertebral centrum of sharks. a: labial; b: lingual; c: lateral; d: occlusal; e: oral views.

- Grinding type in Dasyatdae. Teeth are high crowned and of polygonal shape, closely intertwined and forming a real dental plaque with an almost flat surface. This type is found in fishes preferring benthic habits where they can feed on prey with hard resistant envelopes.

- Clutching-Grinding type of Heterodontidae. Anterior teeth cusps generally provided with lateral denticles are of clutching type, while the lateral teeth, with massive spreading crown more or less cambered are of grinding type. The genera with dentition type prefer benthic habits and live mainly on hard bottoms.

In summary, a relationship between dentition type and living environment, can observed as following:

- The Tearing type is specifically confined to the Lamniformes, confined to coastal and epi-bathyal areas. 
Table 2. Dentition type and occurrence of fish teeth from the Thanetian phosphatic series of Jebel Dyr (Algerian-Tunisian border area).

\begin{tabular}{|c|c|c|}
\hline Family & Dentition types and main features of collected specimens & Occurence \\
\hline $\begin{array}{l}\text { ODONTASPIDIDAE } \\
\quad \text { (Sand sharks) }\end{array}$ & $\begin{array}{l}\text { Tearing type; large dagger-shaped teeth, long and tapering, often with two small, sharp denticles next to } \\
\text { the main crown; small and strong tapering in Odontaspis. The crown is smooth, the root is short with } \\
\text { spaced lobes in Brachycarcharias, or long and close together to Carcharias. }\end{array}$ & Frequent \\
\hline $\begin{array}{l}\text { MITSUKURINIDAE } \\
\text { (Goblin sharks) }\end{array}$ & $\begin{array}{l}\text { Tearing type; small unsymmetrical teeth, thrown towards the commissure with a blunted apex; wide and } \\
\text { low denticles; root large and relatively flat with a deep groove (Striatolamia). }\end{array}$ & Uncommon \\
\hline $\begin{array}{l}\text { OTODONTIDAE } \\
\text { (Megatoothed sharks) }\end{array}$ & $\begin{array}{l}\text { Cutting type; Teeth large robust with unsserrated triangular crown, smooth cutting edges and roughly } \\
\text { triangular side cusps (Otodus). Cretolamna teeth have a compressed root which has a rectangular } \\
\text { looking shape. The main cusp is broad and there are two stocky triangular shaped cusplets. }\end{array}$ & Rare \\
\hline $\begin{array}{c}\text { LAMNIDAE } \\
\text { (Mackerel sharks) }\end{array}$ & $\begin{array}{l}\text { Cutting type; Teeth slack cusplets and have thick, but mesio-distally compressed, roots with nearly vertical } \\
\text { lateral margins and a straight cusp. The lingual protuberance bears an elliptical foramen (Isurolamna). }\end{array}$ & Uncommon \\
\hline $\begin{array}{l}\text { CARCHARHINIDAE } \\
\text { (Requim sharks) }\end{array}$ & $\begin{array}{l}\text { Cutting-Clutching type; teeth are generally small, inclined to a sharp notch between the posterior dentil } \\
\text { and the rest of the crown (Adounia). In general, the crown is blade-like and distally directed. The mesial } \\
\text { cutting-edge continues on to the shoulder and bears weak serrations and can be strongly serrate with up } \\
\text { to four cusplet-like serrations (Physogaleus). }\end{array}$ & Frequent \\
\hline JAEKELOTODONTIDAE & $\begin{array}{l}\text { Tearing type, Mennerotodus teeth have a fine and high main cusp and lateral cuspids that are not well developed. } \\
\text { They are distinguished by the presence of fine crenulations between the crown and the lateral denticles. }\end{array}$ & Rare \\
\hline $\begin{array}{l}\text { TRIAKIDAE } \\
\text { (hound sharks) }\end{array}$ & $\begin{array}{l}\text { Clutching-crushing type: Small ring of teeth flat main cusp highly developed and curved. The denticles } \\
\text { decreasing from top to bottom edge (Galeorhinus). The Mustelus teeth are characterised by a crushing } \\
\text { type dentition. They are slightly asymmetrical and transversely elongated, with a reduced, distally } \\
\text { directed cusp. The crown is as high as the root. }\end{array}$ & Common \\
\hline $\begin{array}{l}\text { SCYLIORHINIDAE } \\
\text { (Cat sharks) }\end{array}$ & $\begin{array}{l}\text { Type Clutching/Tearing; Teeth laterally spread; the outer face is slightly convex. Pairs of lateral denticles } \\
\text { (Scyliorhinus) flank the wide cusp, sharp and angled towards the corner. }\end{array}$ & Rare \\
\hline $\begin{array}{l}\text { SQUATINIDAE } \\
\text { (Shark Angels) }\end{array}$ & $\begin{array}{l}\text { Crushing type; small triangular tooth, its root behind rejects the crown angles. The base of the root has a } \\
\text { rhombic shape (Squatina). }\end{array}$ & Rare \\
\hline $\begin{array}{l}\text { HETERODONTIDAE } \\
\text { (bullhead sharks) }\end{array}$ & $\begin{array}{l}\text { Clutching-grinding type: flat teeth and stretched, without sharp cusps. The labial face of the crown } \\
\text { extends over the splayed root lobes and the apron may bear ornamentation (Heterodontus). }\end{array}$ & Uncommon \\
\hline $\begin{array}{l}\text { GINGLYMOSTOMAT1D } \\
\text { AE (Nurse sharks) }\end{array}$ & $\begin{array}{l}\text { Clutching type: teeth generally small, the number of denticles can multiply gradually and laterally. } \\
\text { (Nebrius). Delpitoscyllium Teeth are longer than broad with a triangular cusp and a pair of divergent } \\
\text { lateral cusplets. The cusplets develop low on the crown face but project relatively high. Occlusally, the } \\
\text { Burnhamia teeth are hexagonal in shape and are arranged in a pavement-like fashion. }\end{array}$ & Frequent \\
\hline $\begin{array}{l}\text { HEMISCYLLIIDAE } \\
\text { (Bamboo sharks) }\end{array}$ & $\begin{array}{l}\text { Clutching type; The teeth have a main tip cusp narrowly triangular and two small lateral tips similar in } \\
\text { each side and have broad-based (Hemiscyllium). }\end{array}$ & Uncommon \\
\hline $\begin{array}{l}\text { ORECTOLOBIDAE } \\
\text { (Wobbegong sharks) }\end{array}$ & $\begin{array}{l}\text { Clutching type, Teeth fairly compressed laterally to high cusp, pointed, inclined inwards. The outer face of } \\
\text { the crown is quite convex. The inner medial protuberance is well developed, long and rather slender at its } \\
\text { end. The root is tall, squat, flat basal face in profile, but concave anteriorly in labial view (Squtiscyllium). }\end{array}$ & Uncomn \\
\hline $\begin{array}{l}\text { MYLIOBATIDAE } \\
\quad \text { (Eagle rays) }\end{array}$ & $\begin{array}{l}\text { Crushing type; Online teeth, dentition plates or real millstones. Palace mills high crown of polygonal contour. } \\
\text { The indented portion is the root of the tooth, the thin crown, is a smooth portion and hard (Myliobatis). }\end{array}$ & Rare \\
\hline $\begin{array}{l}\text { DASYATIDAE } \\
\text { (Whiptail stingrays) }\end{array}$ & $\begin{array}{l}\text { Grinder type: tiny teeth about } 2 \mathrm{~mm} \text {, ornate. The forms found are loops. The root is higher in profile } \\
\text { (Dasyatis). }\end{array}$ & Uncommon \\
\hline $\begin{array}{c}\text { MOBULIDAE } \\
\text { (Mantarays, Devilrays) }\end{array}$ & $\begin{array}{l}\text { Cutting-Clutching type; Teeth Archaeomanta are easily recognized by their peg-like design and bulbous } \\
\text { root. Unlike the living manta ray, the crown rises directly from the root, bears a median ridge and is } \\
\text { fully covered with enameloid. }\end{array}$ & Rare \\
\hline $\begin{array}{l}\text { RAJEDAE } \\
\text { (skates fish) }\end{array}$ & $\begin{array}{l}\text { Crushing type, teeth usually small shaped like inverted trumpets. The anterior and lateral have a cusp } \\
\text { more or less elongated (Raja). }\end{array}$ & Rare \\
\hline $\begin{array}{l}\text { PRISTIDAE } \\
\text { (Sawfish) }\end{array}$ & $\begin{array}{l}\text { Rostral "teeth" (referred herein as spines). The tooth is longer than broad, the crown is globular \& } \\
\text { rounded, has a transverse crest. In general, elongated rostral spines with sharp or smoothly rounded } \\
\text { posterior edges tend to be channeled ones (Pristis). }\end{array}$ & Rare \\
\hline
\end{tabular}


- Cutting type dentition is found in fishes living near the bottom or in open water neritic habitats.

- Subtype cutting/grinding characterises both coastal and bathyal forms.

- The crushing, grinding, grinding/clutching and clutching types are essentially restricted to benthic and nektic forms of the neritic zone.

Table 3 specifies climatic, environmental and bathymetric preference of the species represented in the phosphate series of Jebel Dyr, allow deductions and

Table 3. Environmental preferences of the thanetian ichthyological assemblage recovered from Jebel Dyr phosphatic layers (Algerian-Tunisian border area).

\begin{tabular}{|c|c|c|c|c|c|c|c|c|}
\hline \multirow[b]{2}{*}{ Taxa } & \multicolumn{3}{|c|}{ Climate } & \multicolumn{3}{|c|}{ Environment } & \multicolumn{2}{|c|}{ Bathymetry } \\
\hline & $\begin{array}{c}\text { Tropical/ } \\
\text { Subtropical }\end{array}$ & Temperate & Cold & $\begin{array}{l}\text { Litoral/Neri } \\
\text { tic }\end{array}$ & $\begin{array}{c}\text { Semipelagic/ } \\
\text { Pelagic }\end{array}$ & Bathyal & Nektic & Benthic \\
\hline Brachycarcharias lerichei & 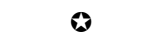 & is & & 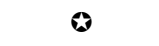 & & & & \\
\hline Odonstaspis winkleri & 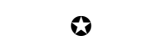 & it & & $\boldsymbol{\theta}$ & & & & \\
\hline Striatolamia striata & $\boldsymbol{\theta}$ & is & & & $\boldsymbol{\theta}$ & is & & $\theta$ \\
\hline Carcharias hopei & 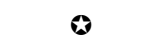 & is & & $\bullet$ & & & & $\boldsymbol{\theta}$ \\
\hline Anomotodon novus & $\bullet$ & is & & & & it & & $\boldsymbol{0}$ \\
\hline Otodus obliquus & $\boldsymbol{0}$ & & & $\boldsymbol{0}$ & & & is & 0 \\
\hline Cretalamna appendiculata & 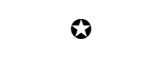 & & & 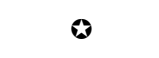 & ts & & 斗 & 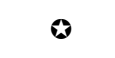 \\
\hline Abdounia beaugei & & 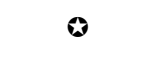 & & $\boldsymbol{\theta}$ & is & & $\theta$ & is \\
\hline Galeorhinus mesetaensis & is & 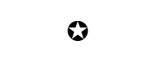 & & $\boldsymbol{\theta}$ & & & & 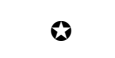 \\
\hline "Scyliorhinus" gilberti & $\boldsymbol{\theta}$ & $\boldsymbol{\theta}$ & & $\boldsymbol{\theta}$ & & & is & $\boldsymbol{\theta}$ \\
\hline Squatina prima & & $\theta$ & & & $\theta$ & is & & 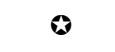 \\
\hline Heterodontus sp & & 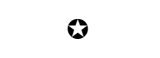 & & is & & & & $\theta$ \\
\hline Isurolamna affinis & & 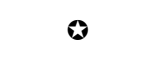 & & 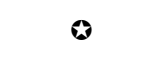 & & & 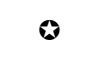 & \\
\hline Archaeomanta priemi & & $\theta$ & & 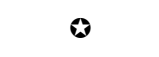 & & & 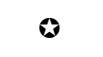 & is \\
\hline Nebrius bequaerti & 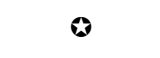 & & & 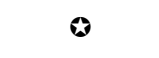 & & & & $\theta$ \\
\hline Delpitoscyllium africanum & 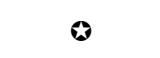 & is & & $\boldsymbol{\theta}$ & ts & & & 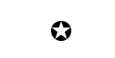 \\
\hline Hemiscyllium daimeriesi & $\bullet$ & & & $\boldsymbol{\theta}$ & is & & & $\boldsymbol{\theta}$ \\
\hline Squatiscyllium nigeriensis & 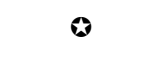 & & & $\boldsymbol{\theta}$ & & & & $\theta$ \\
\hline Myliobatis sulcidens & $\theta$ & is & & & & & & 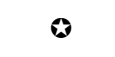 \\
\hline Physogaleus secundus & & 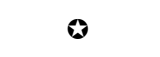 & & $\Delta$ & & & $\theta$ & is \\
\hline Mennerotodus sp. & is & $\bullet$ & & 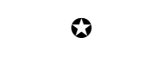 & & & $\theta$ & \\
\hline Palaoegaleus vincenti & & $\boldsymbol{\theta}$ & & $\boldsymbol{\theta}$ & & & & 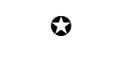 \\
\hline Mustelus biddlei & & 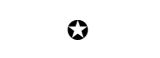 & & $\boldsymbol{0}$ & & & & 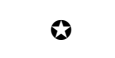 \\
\hline Raja $s p$ & $\theta$ & is & & & is & 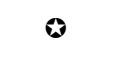 & $\theta$ & \\
\hline Ginglymostoma subafricanum & 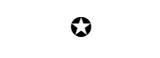 & is & & $\boldsymbol{\theta}$ & is & & & $\theta$ \\
\hline Burnhamia daviesi & 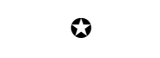 & is & & 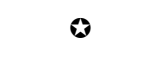 & is & & & $\theta$ \\
\hline Pristis $s p$ & is & 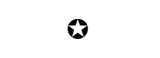 & & is & $\theta$ & & $\theta$ & \\
\hline Dasyatis hexagonalis & $\boldsymbol{\theta}$ & & & $\boldsymbol{\theta}$ & is & & is & $\theta$ \\
\hline
\end{tabular}

is Less characteristic; Characteristic. 
insights which to be drawn from these data:

1) A direct relationship between fish and their distributions on the one hand and the ambient temperature and ocean currents on the other hand.

2) The predominance of forms of warm water at tropical and subtropical distribution such as Brachycarcharias, Carcharias, Odontaspis, Striatolamia, Anomotodon. However, stenothermic forms downright tropical as Otodus are present but in a rare way.

3) Another group of Species preferring temperate or moderately warm water is present: as Abdounia beaugei, Physogaleus secundus, Isurolamna affinis and Archaeomanta priemi.

4) Forms that inhabit temperate or relatively cold waters, as Raja might indicate deeper water environment with lower temperature. Likely, currents can carry sharks from water more or less hot to achieve higher latitude.

5) The majority of the represented fishes inhabit the neritic littoral zone, although some genera, such as Striatolamia striata and Anomotodon novus inhabit the pelagic zone. Others groups such as Raja, which are extremely rare, even live in bathyal zones. Currents allow forms of cold water who live in deep water to appear near shallower water. This may explain the co-occurrence of temperate and warm indicators.

6) Among the recognized Species 07 are nektonic and benthic at a time. With respect to the remaining groups only 04 have a nektic lifestyle otherwise 17 forms are benthic.

In summary, the fish assemblage indicates a relatively warm sea, but not strictly tropical. Thus, most of the forms demonstrate a shallow marine, coastal environment, with occasionally rocky bottoms, suitable for molluscs and shellfish predators, as well as sandy bottoms frequented by small sharks such as Odontaspis the so-called "sand sharks" [24] [25] [26] [27] [28].

Many fish groups encountered in this phosphatic serie still live in the Mediterranean and in the Atlantic Ocean: Carcharias, Galeorhinus, Physogaleus, Mustelus and Raja.

There is a strong resemblance between ichthyologic fauna composition of the Algerian-Tunisian border area (South Tethys) with that of the Anglo-Franco-Belgian basin during the Paleogene [29] [30] [31] [32]. This wide geographical distribution of sharks and rays demonstrates shows their biostratigraphic potential.

Finally, given the geological data and the absence of the purely pelagic and bathyal forms, it can be assumed that this Thanetian assemblage occupied a relatively narrow gulf. The last was between mainland and open sea, agreeing with the paleogeographical interpretation of [33]. It indicating that Tebessa (Dyr) area was immersed between the Algerian promontory and the island of Kasserine (Figure 7 ).

\section{Conclusions}

1) The Jebel Dyr phosphatic serie yielded a wealth of fish remains with many 


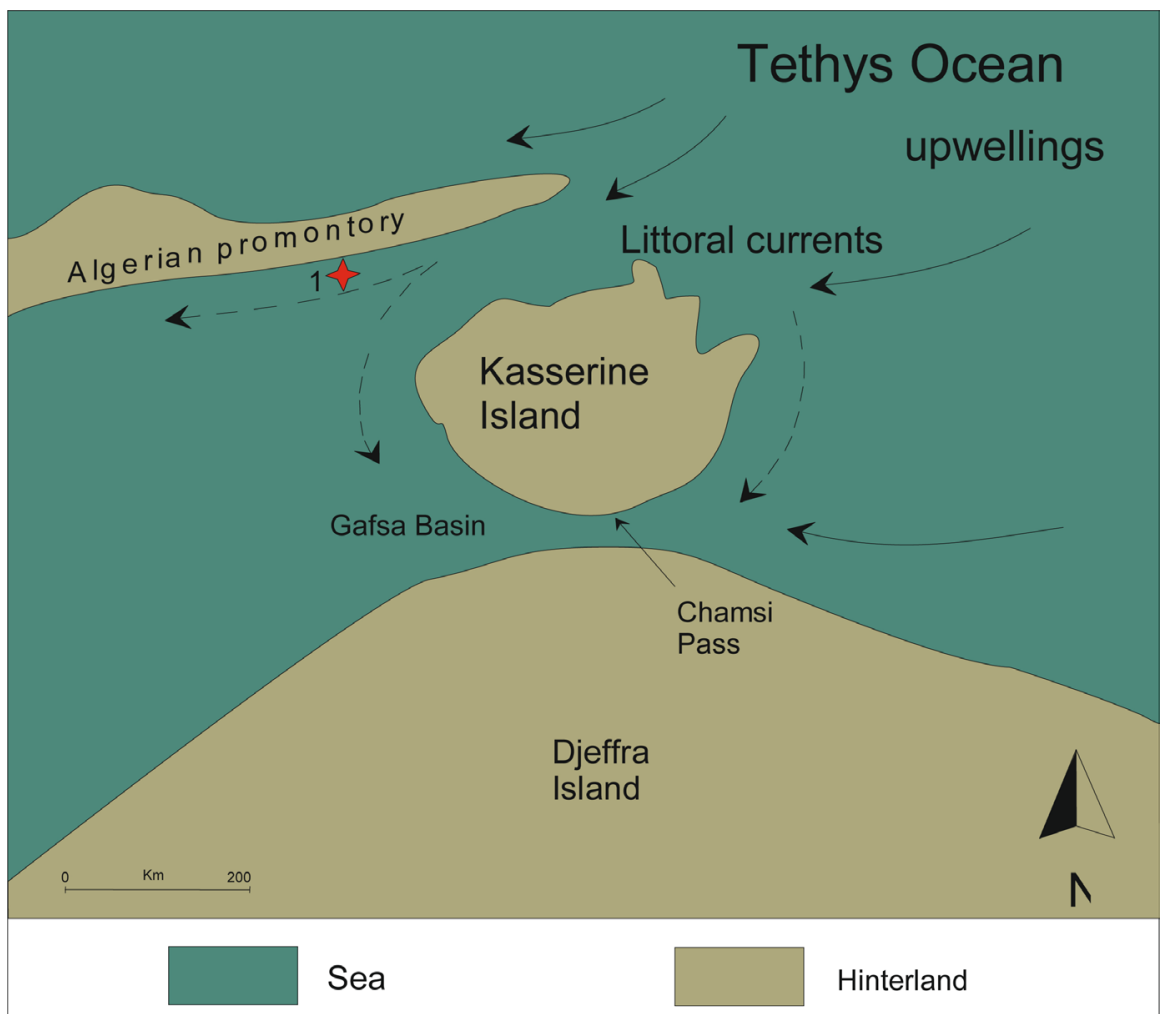

Figure 7. Supposed Paleocene-Eocene paleogeography in Algerian-Tunisian border area ([33], modified). Red star indicates position of sample locality (Jebel Dyr).

predators, represented by 28 species of Elasmobranchii (Euselachii and Batoidea).

2) The fossil forms of the Elasmobranchii recognized in these phosphate layers confirm the Thanetian age for this formation of Jebel Dyr.

3) Dentition types mainly characterize benthic and nectic forms of the neritic littoral.

4) The fish fauna indicates a marine, coastal, shallow water environment with both rocky and sandy bottom, and temperature to subtropical climatic conditions.

5) The appropriate paleobiogeographic indication is almost similar with the most contemporary of the Mediterranean fish.

6) Apparently, the Jebel Dyr assemblage of fish occupied during Thanetian a relatively narrow golf separated from open sea.

We conclude that Jebel Dyr fish fauna preferred inhabit the neritic zonal environments, which gave the highly opportunistic predator ability to prey on various animal groups, such as molluscs (bivalves, gastropods and cephalopods), crustaceans, echinoderms, annelids, sipunculids and fish. The wealth of biota on the continental shelf and upper slope contrasts strongly to the pelagic or bathyal zones, where potential food is less abundantly available, more dispersed and less varied.

\section{Acknowledgements}

We would like to thank students; Rouabhia, T., Selmania, T. \& Maarof A. for 
helping in fieldwork. We are grateful for the help received from Hassan A. in his technical assistance in laboratory. The contributions and facilities of Mr. Omar the head of the Department of Earth Sciences and the Universe, Tebessa University are also much appreciated. We especially thank M. Arie W. Janssen, Naturalis Biodiversity Center, Netherlands for his critically reading the manuscript and mainly his linguistic improvement. Finally, we warmly thank M. Adnet S., Montpellier University, France for his improvement to the manuscript and the redetermination of some species.

\section{Conflicts of Interest}

The authors declare no conflicts of interest regarding the publication of this paper.

\section{References}

[1] Flandrin, J. (1948) Contribution à l'étude stratigraphique du Nummulitique algérien. Bulletin du Service de la Carte géologique de l'Algérie, 19, 1-340.

[2] Boulemia, S., Selmania, T. and Hamimed, M. (2014) Analyse Paléontologique des Phosphorites Sédimentaires Paléo-Éocènes d'El Kouif (Confins Algéro-Tunisiens). European Journal of Scientific Research, 127, 323-334.

[3] Boulemia, S., Hamimed, M., Bouhlel, S. and Bejaoui, J. (2015) Petro-Mineralogical Analysis of Sedimentary Phosphate of Marine Origin, Case of the Locality of El Kouif (Algerian-Tunisian Confines). Open Journal of Geology, 5, 156-173. https://doi.org/10.4236/ojg.2015.53015

[4] Compagno, L.J.V. (1970) Systemalics of the Genus Hemitriakis (Selachii: carcharhinidae), and Related Genera. Proceedings of the California Academy of Sciences, 38, 63-98.

[5] Compagno, L.J.V. (1984) FAO Species Catalogue. Volume 4. Sharks of the World. An Annotated and Illustrated Catalogue of Shark Species Known to Date. Part 1. Hexanchiformes to Lamniformes. Food and Agriculture Organization of the United Nations, Rome, 125-249.

[6] Cappetta, H. (1986) Types dentaires adaptatifs chez les sélaciens actuels et post-paléozoiques. Palaeovertebrata, 16, 57-76.

[7] Noubhani, A. and Cappetta, H. (1992) Évolution de la taille et de la morphologie des dents dans deux lignées de sélaciens: application biostratigraphique. Tertiary Research, 14, 1-18.

[8] Arambourg, C. (1952) Les vertébrés fossiles des gisements de phosphates (Maroc-Algérie-Tunisie). Notes et Mémoires du Service Géologique du Maroc, 92, 1-372.

[9] Casier, E. (1966) Faune ichthyologique du London Clay. Trustees of the British Museum (Natural History), 2, 1-496.

[10] Herman (1977) Les Sélaciens des terrains néo crétacés \& paléocènes de Belgique \& des contrées limitrophes. Eléments d'une bio stratigraphie intercontinentale. Mémoires pour l'Explication des cartes géologiques et minières de la Belgique, 15, $1-450$.

[11] Cappetta, H. (1980) Modification du statut générique de quelques espèces de sélaciens crétacés et tertiaires. Palaeovertebrata, 10, 29-42. 
[12] Cappetta, H. (1987) Mesozoic and Cenozoic Elasmobranchii, Chondrichthyes II. Gustav Fischer, Stuttgart, 193 p.

[13] Cappetta, H. and Nolf, D. (2005) Révision de quelques Odontaspididae (Neoselachii: Lamniformes) du Paléocène et de l'Eocène du Bassin de la mer du Nord (Revision of some Odontaspididae (Neo-selachii: Lamniformes) from the Paleocene and Eocene of the North Sea Basin). Bulletin de I'Institut royal des Sciences naturelles de Belgique, 75, 237-266.

[14] Smith, R. (1999) Elasmohranches nouveaux de la transition Paléocène-Eocène de Dormaal (Belgique). Bulletin de l'Institut royal des Sciences naturelles de Belgique, 69, 173-185.

[15] Antunes, M.T., Jonet, S. and Nascimento, A. (1981) Vertébrés (crocodiliens, poissons) du miocène marin de l'Algarve occidentale. Ciências da Terra, 6, 9-38.

[16] Smith, T. and Smith, R. (1995) Synthèse des données actuelles sur les vertébrés de la transition Paléocène-Éocène de Dormaal. Bulletin de la Société belge de Géologie, 104, 119-131.

[17] Ward, D.J. (1980) The Distribution of Sharks, Rays and Chimaeroids in the English Palaeogene. Tertiary Research, 3, 13-19.

[18] Ward, D.J. and Wiest, R.L. (1990) A Checklist of Palaeocene and Eocene Sharks and Rays (Chondrichthyes) from the Pamunkey Group, Maryland and Virginia, USA. Tertiary Research, 12, 81-88.

[19] Compagno, L.J.V. (2001) Sharks of the World. An Annotated an Illustrated Catalogue of Shark Species Known to Date. Volume 2. Bullhead, Mackerel and Carpet sharks (Heterodontiformes, Lamniformes and Orectolobiformes). FAO Species Catalogue for Fishery Purposes, 1-269.

[20] Leriche, M. (1922) Les poissons paléocènes et éocènes du bassin de paris (Note additionnelle). Bulletin de la société géologique de France, 22, 177-200.

[21] Bles, J.L. and Fleury, J. (1970) Notice explicative de la carte géologique du Morsot (178) Publication du Service géologique de l'Algérie, Alger.

[22] Cappetta, H. (2012) Chondrichthyes: Mesozoic and Cenozoic Elasmobranchii: Teeth. In: Schultze, H.-P., Ed., Handbook of Paleoichthyology, Volume 3E, Verlag Dr. Friedrich Pfeil, Munich, 1-512.

[23] Moss, S.A. (1977) Feeding Mechanism in Sharks. American Zoologist, 17, 164-355. https://doi.org/10.1093/icb/17.2.355

[24] Cyril, G., Judicael, P. and Gael, P. (2009) Le gisement de vertébrés Thanétiens (paléocène supérieur, MP6) du petit Patis prés Creil (Oise, France). Bulletin d'information du Bassin de Paris, 46, 3-11.

[25] Davis, Z. (2016) Elasmobranchii: A Survey Study on the Impact of Our Everyday Choices in Marine Environments. Biology Honors Papers, 23. http://digitalcommons.conncoll.edu/biohp/23

[26] Dutheil, D.B., Moreau, F. and De Plöeg, G. (2006) Les ichthyofaunes du gisement à ambre de Le Quesnoy (Paléocène et Éocène du bassin de Paris, France). Cossmanniana, 11, 1-13.

[27] Ebert, D.A. and Stehmann, M.F.W. (2013) Sharks, Batoids, and Chimaeras of the North Atlantic. FAO Species Catalogue for Fishery Purposes, 7, 1-523.

[28] Moreau, F. and Mathis, S. (2000) Les élasmobranches du Thanétien (Paléocène) du Nord de la France, des carrières de Templeuve et Leforest. Cossmanniana, 7, 1-18.

[29] Smith, R., Smith, T. and Steurbaut, E. (1999) Les élasmobranches de la transition 
Paléocène-Eocène de Dormaal (Belgique): Implications biostratigraphiques et paléobiogéographiques. Bulletin de la société géologique de France, 170, 327-334.

[30] Dutheil, D.B. (1991) A Checklist of Neoselachii (Pisces, Chondrichthyes) from the Palaeogene of the Paris Basin, France. Tertiary Research, 13, 27-36.

[31] Nolf, D. (1988) Dents de requins et de raies du Tertiaire de la Belgique, Fossiles de Belgique. Bulletin de I'Institut royal des Sciences naturelles de Belgique, 1-184.

[32] Baut, J.-P. and Génault, B. (1995) Contribution à l'étude des élasmobranches du Thanétien (Paléocène) du bassin de Paris. Service Géologique de Belgique, Papier Professionnel, 278, 185-259.

[33] Sassi, S. (1974) La sédimentation phosphatée au Paléocène dans le Sud et le Centre Ouest de la Tunisie. Thèse Doct. Ès-Sci. Univ. Paris-Sud Orsay. 